\title{
Rancang Bangun Prototipe Pengatur Kelembaban Tanah Sekaligus Penyiraman Otomatis (PROMATAN SERATIS)
}

\author{
Wahyu Titis Satria Utama, Syaefudhin \\ Program Studi Teknik Elektro \\ Universitas Muhammadiyah Surakarta (UMS) \\ Surakarta, Indonesia \\ d400160032@student.ums.ac.id, \\ d400160002@student.ums.ac.id,
}

\author{
Aditya Putra Yusanta, Febriani Dara Ninggar, \\ Pracilia Ayu Yulia Savega \\ Program Studi Teknik Kimia \\ Universitas Muhammadiyah Surakarta (UMS) \\ Surakarta, IndonesiaCity \\ d500160130@student.ums.ac.id \\ d500160165@student.ums.ac.id \\ d500160134@student.ums.ac.id
}

\begin{abstract}
Abstraksi- Kelembaban tanah menjadi salah satu faktor penting yang mempengaruhi pertumbuhan dari suatu tanaman. Salah satu cara untuk mengetahui kelembaban tanah adalah dengan menggunakan alat pengatur kelembaban tanah. Namun sekarang ini alat pengatur kelembaban tanah belum banyak di gunakkan oleh masyarakat khususnya para petani untuk di implementasikan pada usaha mereka. Perancangan alat pengatur kelembaban tanah sekaligus penyiraman otomatis dengan system arduino ini dirancang untuk mengetahui angka kelembaban tanah suatu tanaman dan akan menyiram secara otomatis jika tanah tersebut berada pada tingkat kelembaban yang rendah. Pada alat ini digunakkan SMH (Soil Moisture Hygrometer) yang akan bekerja dengan cara mengukur kelembaban tanah lalu menyalurkan data kelembaban ke dalam mikrokontroler. Jika data menunjukkan tingkat kelembaban yang rendah, $L E D$ akan menyala dan tanah akan tersiram secara otomatis. Sedangkan jika data menunjukkan tingkat kelembaban yang tinggi makan $L E D$ tidak akan menyala dan alat ini tidak menyirami tanah.
\end{abstract}

Katakunci-kelembaban; tanah; penyiram; otomatis

\section{Pendahuluan}

Dewasa ini industri terus mengalami perkembangan, terutama industri yang bergerak di bidang manufaktur. Dalam industri manufaktur desain suatu produk menjadi bagian yang sangat penting mengingat begitu ketatnya persaingan dan cepatnya inovasi - inovasi yang dikeluarkan oleh produsen untuk mendapatkan pasar penjualan [1].

Sejalan dengan perkembangan teknologi yang semakin pesat dan juga dengan bertambahnya populasi manusia, menyebabkan terjadinya krisis kebutuhan air karena penggunaan secara terus menerus dalam jumlah besar oleh manusia. Ironisnya air merupakan kebutuhan yang paling utama bagi seluruh mahluk hidup. Pada saat musim kemarau keberadaan air semakin langka untuk digunakan pada lahan pertanian. Untuk mendapatkan hasil pertanian yang maksimal dan mengurangi penggunaan air yang sia - sia, pemberian air pada lahan pertanian tidak boleh kurang atau lebih. Karena pemberian air yang kurang atau berlebihan pada tumbuhan dapat menyebabkan tumbuhan tersebut kering atau busuk. Salah satu cara untuk mengetahui apakah air yang dibutuhkan tanaman sesuai dengan kebutuhannya, dapat dilihat dari kelembabantanahnya [2].

Berdasarkan latar belakang tersebut, maka terciptalah inovasi dibidang penerapan teknologi yang direalisasikan dalam pembuatan prototype pengatur kelembaban tanah sekaligus penyiraman otomatis (PROMATAN SERATIS). PROMATAN SERATIS adalah alat pengatur kelembaban tanah sekaligus penyiraman otomatis dengan system arduino dan menggunakkan Soil Moisture Hygrometer. Alat ini akan bekerja dengan cara mengukur kelembaban tanah lalu menyalurkan data kelembaban kedalam mikrokontroler. Jika data menunjukkan tingkat kelembaban yang rendah, $L E D$ akan menyala dan tanah akan tersiram secara otomatis. Sedangkan jika data menunjukkan tingkat kelembaban yang tinggi maka $L E D$ tidak akan menyala dan alat ini tidak menyirami tanah.

\section{Metode}

Penelitian ini dilaksanakan dengan empat tahapan dengan tahapan pertama adalah perancangan alat. Tahap perancangan merupakan tahap dalam melakukan perancangan desain meliputi perancangan model alat yang sederhana dan sesuai. Perancangan meliputi perancangan system kerja alat dan perancangan komponen yang akan digunakan. Cara kerja alat 
yang dirancang yaitu dengan cara mengukur kelembaban tanah lalu menyalurkan data kelembaban kedalam mikrokontroler. Jika data menunjukkan tingkat kelembaban yang rendah, $L E D$ akan menyala dan tanah akan tersiram secara otomatis. Sedangkan jika data menunjukkan tingkat kelembaban yang tinggi maka $L E D$ tidak akan menyala dan alat ini tidak menyirami tanah.

Tahap selanjutnya adalah persiapan alat dan komponen. Pada tahap ini peralatan yang digunakan yaitu solder, obeng, tang, multimeter, dan komponen elektronika. Sedangkan komponen yang digunakan yaitu Arduino, Soil Moisture Sensore, relay, LED, pompa DC atau selenoid valve water, dan selang air.

Tahapan yang ketiga adalah tahap pembuatan alat. Tahap pembuatan alat dimulai dengan membuat desain board micro controller yang dilakukan pada aplikasi eagle, setelah itu desain dicetak atau di convert dalam bentuk file pdf. Kemudian desain dalam bentuk file pdf tersebut disablon pada PBC dan dilarutkan. Lalu menguji board tersebut. Setelah itu komponen elektronika atau micro controller dipasang sesuai desain. Setelah micro controller berhasil dipasang, maka dilakukan pengujian hardware atau board yang telah dibuat. Kemudian melakukan uji coba program. Jika semua sudah berjalan dengan baik, maka dilakukan proses pemrograman atau algoritma sesuai dengan masalah tingkat kelembaban yang ada. Setelah uji coba pemrograman dan hardware, alat yang sudah jadi di uji coba pada media tanah tanaman hias. Kemudian membuat desain body atau casing dari alat tersebut.

Tahap terakhir adalah tahap pengujian alat. Sensor menghitung kelembaban tanah, kemudian data kelembaban yang didapatkan akan di tampilkan pada LCD. PROMATAN SERATIS ini memiliki $L E D$ yang berfungsi untuk mengetahui tingkat kelembaban tanah. Jika warna indikator $L E D$ berwarna merah itu berarti kadar kelembaban pada tanah tersebut rendah. Kemudian jika indikator $L E D$ berwarna biru itu berarti kadar kelembaban pada tanah tersebut tinggi. Jika LED berwarna merah maka sensor memerintahkan solenoid water valve untuk menyiram secara otomatis sesuai dengan kelembabanya.

\section{Hasil dan Pembahasan}

Hasil tampilan fisik dari perancangan alat ini dapat dilihat pada Gambar berikut ini. Gambar 1 merupakan tampilan fisik ketika box ditutup yang mana terdapat $L C D$ dan keypad. Gambar 2 merupakan tampilan fisik ketika box dibuka. Selanjutnya pada hasil penelitian dan percobaan terbukti ketika saklar untuk menghidupkan alat diaktifkan maka indikator $L E D$ warna merah dan biru menyala yang artinya alat ini sudah aktif. Tampilan indikator nyala LED warna merah dan biru dapat dilihat pada Gambar 3.

Pada langkah selanjutnya, jika kontroller ingin menunjukkan angka kelembaban dari tanah maka sensor kelembaban harus ditancapkan terlebih dahulu ke dalam tanah, hasil dapat dilihat pada Gambar 4. Kontroller ini dapat mengkontrol 5 sensor dalam satu potnya.Setelah sensor ditancapkan ke tanah, sensor akan menghitung kelembaban tanah kemudian data yang didapatkan akan ditampilkan pada LCD, hasil dapat dilihat pada Gambar 5. Jika data yang didapatkan sesuai dengan batas normal kelembaban dari tanah tersebut, maka $L E D$ akan berwarna biru dan alat tidak menyiram tanaman, hasil dapat dilihat pada Gambar 6 . Namum, jika data yang didapatkan kurang dari batas normal kelembaban dari tanah tersebut, maka $L E D$ akan berwarna merah dan alat akan menyiram tanaman hias secara otomatis, hasil dapat dilihat pada Gambar 7.

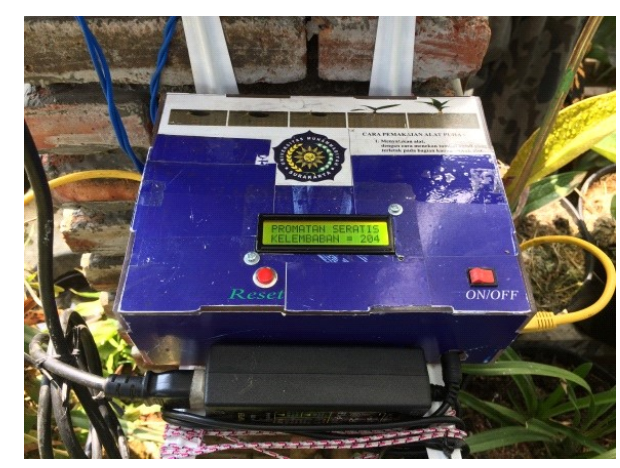

Gambar 1. Tampilan fisik ketika box ditutup.

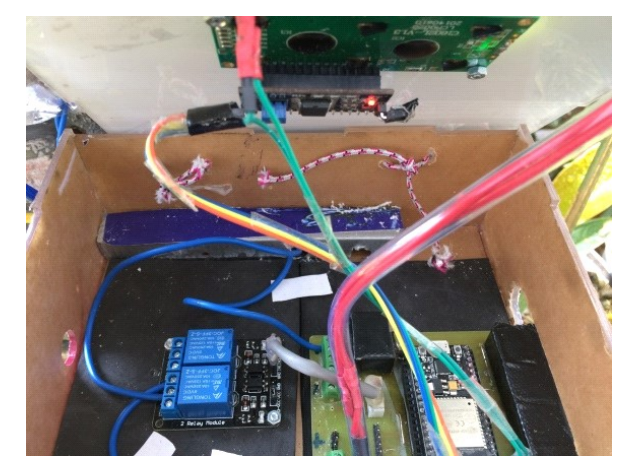

Gambar 2. Tampilan fisik ketika box dibuka.

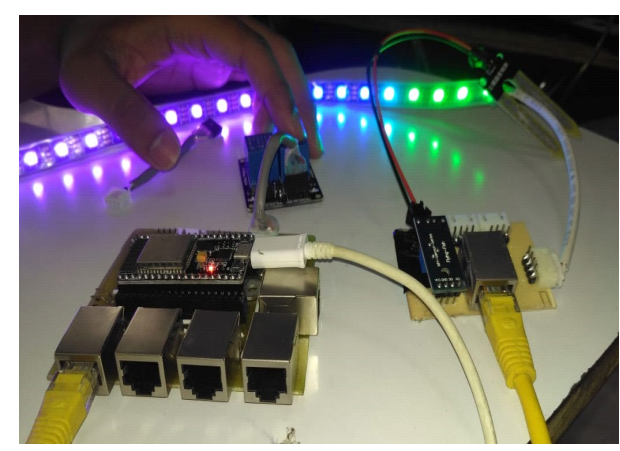

Gambar 3. Tampilan saat $L E D$ menyala. 

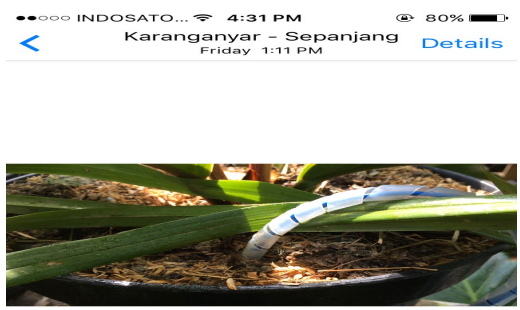

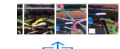

「个]

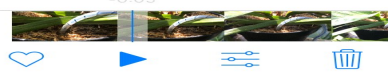

Gambar 4. Tampilan saat sensor ditancapkan ke dalam tanah.

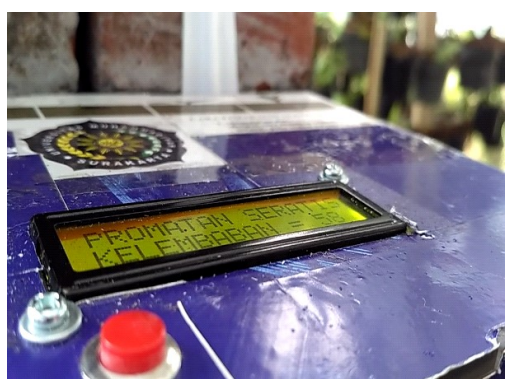

Gambar 5. Tampilan data kelembaban tanah

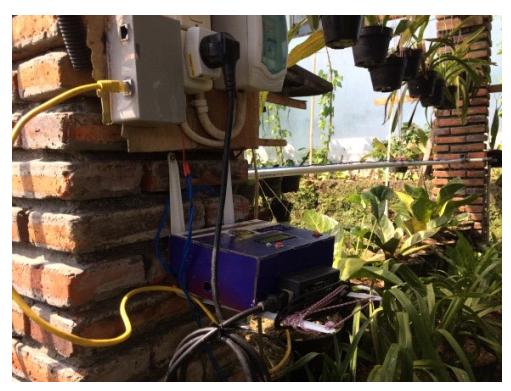

Gambar 6. Tampilan saat alat tidak menyiram tanaman.

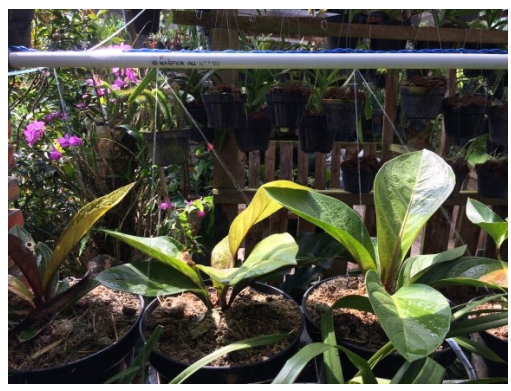

Gambar 7. Tampilan saat alat tidak menyiram tanaman.
Tabel I. Hasil Pengujian Alat

\begin{tabular}{|c|c|c|c|c|}
\hline No. & $\begin{array}{c}\text { Skenario } \\
\text { Pengujian }\end{array}$ & $\begin{array}{l}\text { Hasil yang } \\
\text { Diharap }\end{array}$ & Pengamatan & Kesimpulan \\
\hline 1 & $\begin{array}{l}\text { Mengaktifkan } \\
\text { saklar }\end{array}$ & $\begin{array}{l}L E D \text { merah } \\
\text { dan biru } \\
\text { menyala } \\
\text { sebagai tanda } \\
\text { alat sudah } \\
\text { aktif }\end{array}$ & $\begin{array}{l}L E D \text { merah } \\
\text { dan biru } \\
\text { menyala yang } \\
\text { menandakan } \\
\text { alat sudah } \\
\text { aktif }\end{array}$ & Berhasil \\
\hline 2 & $\begin{array}{l}\text { Sensor ditanam } \\
\text { pada tanah } \\
\text { tanaman hias }\end{array}$ & $\begin{array}{l}\text { Muncul } \\
\text { output pada } \\
L C D\end{array}$ & $\begin{array}{l}\text { Output } \\
\text { muncul pada } \\
L E D \text { yang } \\
\text { menandakan } \\
\text { sensor dapat } \\
\text { mendeteksi } \\
\text { kelembaban } \\
\text { tanah }\end{array}$ & Berhasil \\
\hline 3 & $\begin{array}{l}\text { Mengamati } \\
\text { warna } L E D\end{array}$ & $\begin{array}{l}\text { Jika } L E D \\
\text { berwarna } \\
\text { merah maka } \\
\text { tingkat } \\
\text { kelembaban } \\
\text { rendah, } \\
\text { sedangkan } \\
\text { jika } L E D \\
\text { berwarna biru } \\
\text { maka } \\
\text { kelembaban } \\
\text { tinggi }\end{array}$ & $\begin{array}{l}L E D \\
\text { berwarna } \\
\text { merah } \\
\text { sehingga } \\
\text { tanaman } \\
\text { tersiram } \\
\text { secara } \\
\text { otomatis }\end{array}$ & Berhasil \\
\hline
\end{tabular}

\section{KESIMPULAN}

Berdasarkan percobaan dan pengamatan yang telah dilakukan, alat yang dibuat untuk mengukur nilai kelembaban tanah dan penyiraman otomatis ini dapat berfungsi dengan.Alat ini dapat bekerja sesuai dengan nilai batas kelembaban yang diinginkan, sehingga dapat digunakan untuk mengendalikan penyiraman tanah.Alat pengukur kelembaban tanah sekaligus penyiraman otomatis ini dengan komponenkomponen yang digunakan dapat direalisasikan dengan harga yang relatif murah.

\section{Daftar Pustaka}

[1] Sumantri, Dede. David. Peningkatan Kinerja Mesin Rapid Prototyping Berbasis Fused Deposition Modelling. Universitas Indonesia, Jakarta, 2010.

[2] Stefanus dan D. Setia. 2013. Alat Pengukur Kelembaban Tanah Berbasis Mirokontroler PIC 16F84.” Indonesian Journal Of Physics”. 3(1):36-40.

[3] Sawidin S, Olga E M, Tracy M. 2015. Monitoring Kontrol Greenhouse untuk Budidaya Tanaman Bunga Krisan dengan Lab View. 4(4).

[4] Erdyanto H, Arif L F, Galih J S, Masruroh, Herlambang S P. 2017. Top Coys ( Automated Plant Controlling Systems): Solusi Pengendalian Lingkunagn Pada Budidaya Bunga Krisan Di Asosiasi Tani "Astha Bunda" Kaliurang. 1(1):86-91.

[5] Erdyanto H, Arif L F, Galih J S, Masruroh, Herlambang S P. 2017. Top Coys ( Automated Plant Controlling Systems): Solusi Pengendalian Lingkunagn Pada Budidaya Bunga Krisan Di Asosiasi Tani "Astha Bunda” Kaliurang. 1(1):86-91. 